Cite this: NewJ. Chem., 2013, 37, 3770

Received (in Montpellier, France) 14th June 2013,

Accepted 27th August 2013

DOI: $10.1039 /$ c3nj00641g

www.rsc.org/njc

\title{
The metallacrowns as templates for spontaneous self-assembly of polypeptides into a tetrahelical bundle $\dagger$
}

\author{
Marta Cal, ${ }^{a}$ Łukasz Jaremko, ${ }^{b}$ Mariusz Jaremko ${ }^{c}$ and Piotr Stefanowicz ${ }^{* a}$
}

\begin{abstract}
Amphiphilic peptide sequences with $\beta$-aminohydroxamic acid ( $\beta a h x)$ at their C-termini were complexed with $\mathrm{Cu}^{2+}$ ions resulting in formation of stable metallacrowns composed of $\beta$ ahx and copper. The ESI-MS data for the obtained compounds show formation of supramolecular structures of $M_{\mathrm{W}}$ approx. 7000 Da with the compositions corresponding to metallacrowns. The addition of $\mathrm{Cu}^{2+}$ to a solution of $\beta$ ahx-containing peptides results in distinct changes in the $C D$ spectra indicating a shift of their conformational equilibria toward helical structures. The experiments with enzymatic hydrolysis show that formation of metallacrown systems significantly increases the proteolytic stability of investigated peptides.
\end{abstract}

\section{Introduction}

Despite the accumulation of a large body of information on the protein folding and structures, designing stable artificial proteins is a difficult task. This problem can be simplified significantly by preorganization of relatively short peptides with predictable conformational preferences on a rigid template assuring the orientation of peptide chains optimal for formation of defined secondary structures. This approach was initiated by Manfred Mutter who introduced the concept of TASP (template assembled synthetic proteins). The first molecules based on the TASP concept resulted from attachment of short amphipathic peptides with high helical propensities to a cyclic peptide playing the role of a relatively rigid template. ${ }^{1}$ The structure of the template was modified in further investigations and currently there are many examples of applying various types of molecules including peptides, carbohydrates, porphyrins, steroids, calixarenes, and cavitands as scaffolds. ${ }^{2}$ The important characteristic of a TASP molecule is that the peptides are attached to the template by stable covalent bonds. On the other hand, such structures can be formed by peptides containing moieties with a large hydrogen bond or metal-complexation potential. ${ }^{3}$ Such a design makes the TASP molecule a reversible, dynamic system, which can be studied by the methods of combinatorial chemistry.

\footnotetext{
${ }^{a}$ Faculty of Chemistry, University of Wroctaw, Joliot-Curie 14, 50-383 Wrockaw, Poland. E-mail: piotr.stefanowicz@chem.uni.wroc.pl; Fax: +48 71-328-23-48

${ }^{b}$ Max Planck Institute for Biophysical Chemistry and German Center for Neurodegenerative Diseases, Am Fassberg 11, 37077 Gottingen, Germany ' Department for NMR-based Structural Biology, Max Planck Institute for Biophysical Chemistry, Am Fassberg 11, 37077, Goettingen, Germany $\dagger$ Electronic supplementary information (ESI) available. See DOI: 10.1039/ c3nj00641g
}

A successful attempt to design polypeptides which form a defined structure (triple helix bundle) in the presence of a metal ion has been previously reported. ${ }^{4}$ An amphipathic peptide sequence was conjugated with a derivatized bipyridyl moiety. Conjugates synthesized in the presence of transition metal ions formed a triple helix bundle which was evidenced by CD spectra as well as by an ESI-MS technique. Additionally, the independent determination of molecular mass by gel filtration confirmed that the trimetric form is predominant in solution. The abovementioned system was further studied by various methods and applied as a platform for the search for stable arrangements of triple helices by dynamic combinatorial chemistry.

Herein we present a new dynamic scaffold which can be used for designing self-assembling systems. This scaffold is based on a metallacrown - a stable structure formed by aminohydroxamic acids in the presence of copper(II) ions. The metallacrown assembly has been previously described. ${ }^{5}$ This supramolecule is formed by 4 aminohydroxamate ligands and $5 \mathrm{Cu}^{2+}$ ions. Many papers have documented the stability and geometry of the formed metallacrown. The literature data suggest that the metallacrown scaffold may be an interesting template for self-assembly of peptide chains. This molecule is stable in water solution. The complex with the $\mathrm{L}_{4} \mathrm{Cu}_{5}$ stoichiometry is reported to be the only species at pH from 5 to 10 . The metallacrown is a relatively rigid molecule and its geometry is similar to that of the template described by Mutter. The structure of this molecule enables the formation of the models of tetrahelical bundles ${ }^{6}$ - the supersecondary structures common in many proteins. Another interesting property of the metallacrown system is its possible chirality resulting from the application of chiral building blocks as the supramolecule components. In this case the relative orientation of peptide backbones is controlled by the chirality of the aminohydroxamate moiety. ${ }^{7}$ 


\section{Results and discussion}

\section{Design and synthesis of peptides}

The literature data show a high stability of complexes formed by aminohydroxamic acids with ions of transition metals. The interactions of $\mathrm{Cu}^{2+}$ ions with aminohydroxamic acids result in formation of supramolecular structures with the $\mathrm{L}_{4} \mathrm{Cu}_{5}$ stoichiometry. The stability of metallacrowns formed by $\alpha, \beta$, and $\gamma$ aminohydroxamic acids and $\mathrm{Cu}^{2+}$ ions changes in the following order: $\beta>\gamma>\alpha{ }^{8}$ There are also reports on formation of stable supramolecular structures by histidine hydroxamic acid, but in this case the metallacrown structure is formed by the hydroxamic and imidazoyl moieties. ${ }^{9}$

In our study we decided to combine a stable metallacrown formed by the $\beta$-hydroxamic acid with the amphiphilic peptide sequences applied by Mutter as the constituents of TASP. ${ }^{10}$ To study the influence of the side chain charge on formation of the "dynamic TASP", in addition to the hydroxamic acidcontaining modified peptide sequence used by Mutter ([AD]-NHOH), we synthesized also [ADE]-NHOH and [ADK]-NHOH sequences composed of only negatively or only positively charged side chains, respectively. All the synthesized peptides were acetylated on their $\mathrm{N}$-termini to avoid the interactions of $\mathrm{Cu}^{2+}$ ions with $\mathrm{N}$-terminal $\alpha$-amino groups. All peptides were obtained on a ChemMatrix ${ }^{\circledR}$ resin derivatized according to a procedure described recently. ${ }^{11}$ The sequences of all peptides investigated in this study are presented in Scheme 1.

In the synthesis of [AD]-NHOH, [ADE]-NHOH, and [ADK]-NHOH, the first amino acid attached to the hydroxylamine resin was Boc-Asp-EDA-Fmoc ${ }^{11}$ - the derivative of aspartic acid in which the $\beta$-carboxylic group is attached to the resin, while the $\alpha$-carboxylic group is derivatized by $N$-Fmoc-ethylenediamine (Fmoc-EDA).

We also synthesized peptides containing histidine hydroxamate at the C-termini ([AH]-NHOH and [AH1]-NHOH) as well as peptide $[\mathrm{AD}]-\mathrm{NH}_{2}-$ the analogue of peptide $[\mathrm{AD}]-\mathrm{NHOH}$, in which the C-terminal hydroxamate moiety was replaced by an amide group. The last compound was used as a negative control.

The details of synthesis of peptides has been described in a separate paper. ${ }^{11}$ The analytical data of all obtained compounds are presented in the Experimental section.

\section{ESI-MS study on metallacrown formation}

The obtained peptides were investigated by the ESI-MS technique for their ability to form supramolecular structures. All the compounds were dissolved in the water-methanol 1:1 system containing ammonium carbonate $\left(10^{-2} \mathrm{M}\right)$. The concentration of the peptide was $10^{-4} \mathrm{M}$ and the concentration of $\mathrm{Cu}^{2+}$ ions was $1.25 \times 10^{-4} \mathrm{M}$ (ligand : $\mathrm{Cu}^{2+}$ ratio $=4: 5$ ). The solution was incubated for $30 \mathrm{~min}$ and then infused directly into the ion source. An analogical measurement was also performed for the $1: 1$ mixture of peptides $[\mathrm{ADK}]-\mathrm{NHOH}$ and $[\mathrm{ADE}]-\mathrm{NHOH}$. The spectrum obtained for the [AD]-NHOH peptide and copper(II) ions is presented in Fig. 1. The data for other ligands are presented in the ESI. $\dagger$ In each case, the spectra show formation of complexes with the $\mathrm{L}_{4} \mathrm{Cu}_{5}$ stoichiometry. The obtained compounds form a series of ions with a charge in the range
A)

Ac-KALEKALKEALAKLH - NHOH

$[\mathrm{AH}]-\mathrm{NHOH}$

Ac-KALEKALKEALAKL $\beta A H$ - NHOH

[AH1]-NHOH

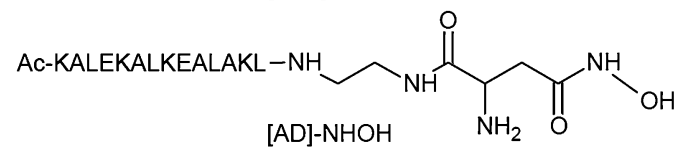

Ac-KALKKALKKALAKL-NH_L

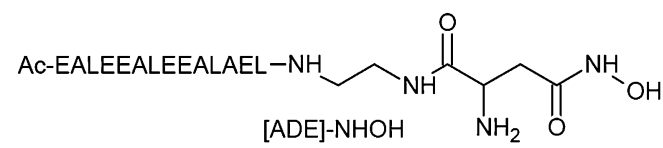

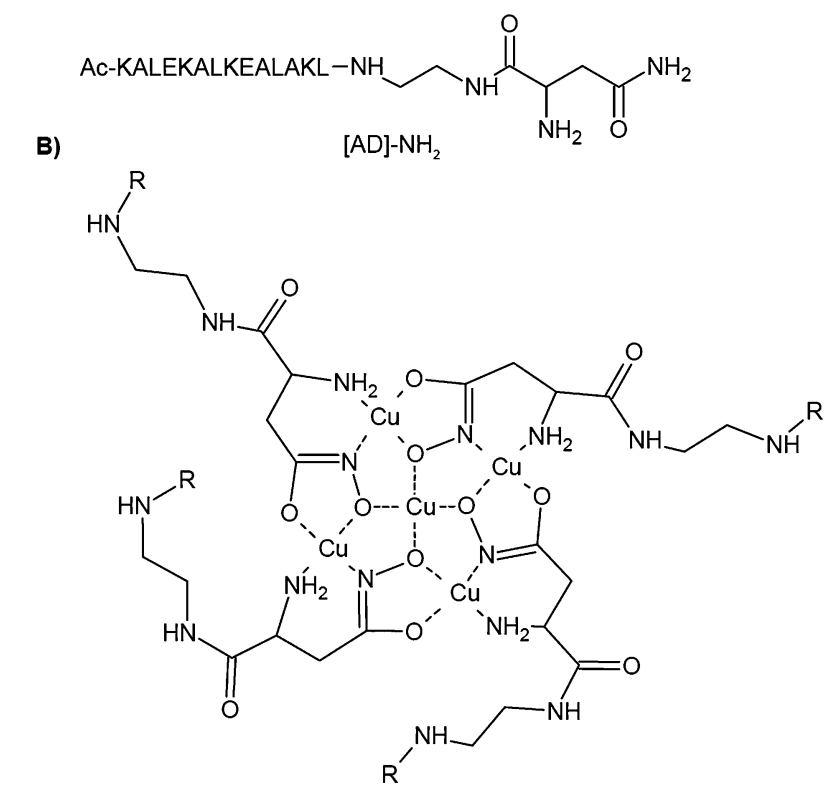

Scheme 1 Panel (A) the sequences of investigated peptides. Panel (B) metallacrown coordination motif, based on literature data. ${ }^{9} \mathrm{R}$ stands for polypeptide chains.

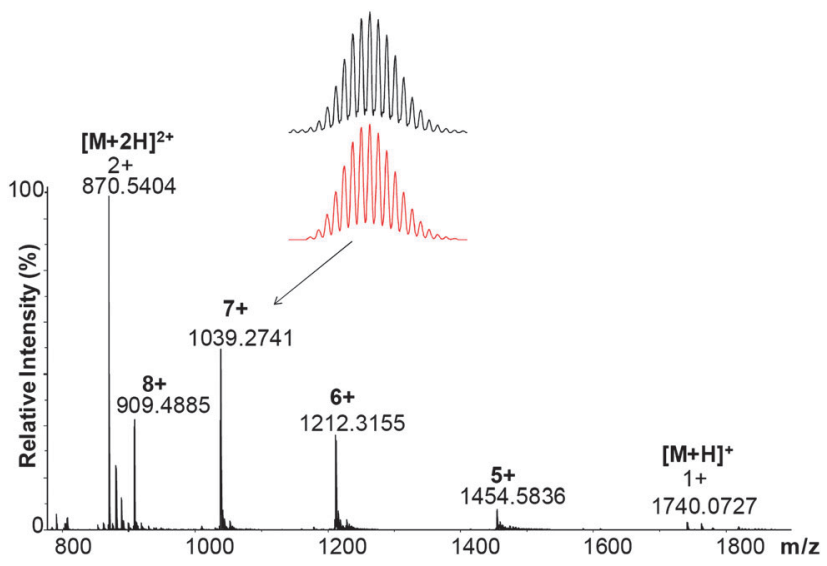

Fig. 1 The MS spectrum of the [AD]-NHOH peptide and its complex with copper(॥) ions. 
Table 1 The comparison of $\mathrm{m} / \mathrm{z}$ values (experimental and calculated) for the most abundant isotopic peaks of metallacrowns formed by the [AD]-NHOH peptide

\begin{tabular}{lllll}
\hline Peptide & $z$ & $\begin{array}{l}\text { Experimental } \\
m / z \text { value }\end{array}$ & $\begin{array}{l}\text { Calculated } \\
m / z \text { value }\end{array}$ & $\begin{array}{l}\text { Elemental formula } \\
\text { of complex }\end{array}$ \\
\hline$[\mathrm{AD}]-\mathrm{NHOH}$ & $5+$ & 1454.5836 & 1454.5764 & $\mathrm{C}_{312} \mathrm{H}_{563} \mathrm{~N}_{88} \mathrm{O}_{88} \mathrm{Cu}_{5}$ \\
& $6+$ & 1212.3155 & 1212.3149 & $\mathrm{C}_{312} \mathrm{H}_{564} \mathrm{~N}_{88} \mathrm{O}_{88} \mathrm{Cu}_{5}$ \\
& $7+$ & 1039.2741 & 1039.2710 & $\mathrm{C}_{312} \mathrm{H}_{565} \mathrm{~N}_{88} \mathrm{O}_{88} \mathrm{Cu}_{5}$ \\
& $8+$ & 909.4885 & 909.4880 & $\mathrm{C}_{312} \mathrm{H}_{566} \mathrm{~N}_{88} \mathrm{O}_{88} \mathrm{Cu}_{5}$ \\
& $9+$ & 808.5459 & 808.5457 & $\mathrm{C}_{312} \mathrm{H}_{567} \mathrm{~N}_{88} \mathrm{O}_{88} \mathrm{Cu}_{5}$
\end{tabular}

from +5 to +10 . Only the $[\mathrm{ADE}]-\mathrm{NHOH}$ peptide does not show the peaks of a complex in the positive ion mode. However, even in this case the complex with the same stoichiometry was observed in the negative ion mode. The molecular formula of each complex was verified on the basis of HR-MS. The calculated and experimental values of $\mathrm{m} / \mathrm{z}$ for the most abundant isotopic peaks presented in Table 1, as well as in the ESI $\dagger$ (Table S1) demonstrated a good agreement with the calculated masses. The $\mathrm{L}_{4} \mathrm{Cu}_{5}$ systems were predominant complexes observed by the ESI-MS method.

Selected complexes were also studied by the MS/MS technique. The obtained data demonstrate that these systems are relatively stable in the gas phase, in contrast to the peptide clusters often observed in the ESI spectra of peptides at high concentrations. Observed fragmentation patterns show breaking of the peptide bonds rather than dissociation of complexes with a free ligand formation. In the ESI-MS spectrum of the "mixed" system, composed of $[\mathrm{ADK}]-\mathrm{NHOH}$ and $[\mathrm{ADE}]-\mathrm{NHOH}$ peptides, mainly the $([\mathrm{ADK}]-\mathrm{NHOH})_{2}([\mathrm{ADE}]-\mathrm{NHOH})_{2} \mathrm{Cu}_{5}$ and $([\mathrm{ADK}]-\mathrm{NHOH})_{3}([\mathrm{ADE}]-$ $\mathrm{NHOH}) \mathrm{Cu}_{5}$ complexes were found (Fig. 2).

An additional experiment was performed for the $[\mathrm{AD}]-\mathrm{NH}_{2}$ peptide. This compound has an identical amino acid sequence to the $[\mathrm{AD}]-\mathrm{NHOH}$ peptide, but contains an amide instead of a hydroxamic moiety at the C-terminus. The ESI-MS spectrum does not show the presence of supramolecular structures. The abundance of the complex with $\mathrm{Cu}^{2+}$ ions is low and the predominant $\mathrm{Cu}^{2+}$ containing system is a mononuclear complex - $\mathrm{LCu}$. The spectrum of the analysed compound is presented in the ESI $\dagger$ (Fig. S6).

\section{Circular dichroism}

The obtained peptides were investigated by the CD method. The measurements were performed in ammonium bicarbonate $\left(10^{-2} \mathrm{M}\right)$ and the concentration of peptides and copper(II) ions was the same as in the MS experiments. The results obtained for $[\mathrm{AD}]-\mathrm{NHOH}$ and $[\mathrm{AD}]-\mathrm{NH}_{2}$ peptides in the presence and absence of $\mathrm{Cu}^{2+}$ ions are presented in Fig. 3. The data concerning other ligands are given in the ESI. $†$
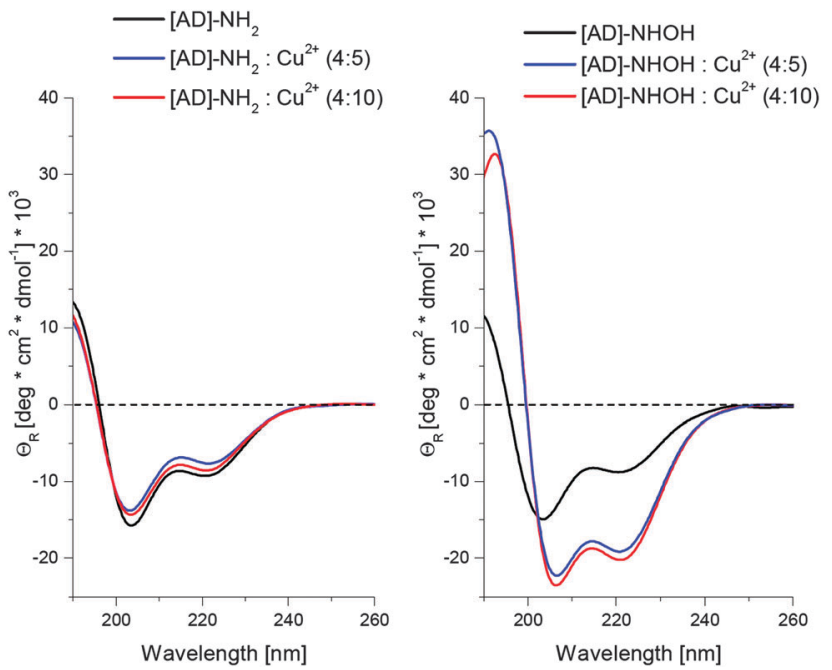

Fig. 3 The $\mathrm{CD}$ spectra of $[A D]-\mathrm{NHOH}$ and $[A D]-\mathrm{NH}_{2}$ peptides and their complexes with copper(II) ions. The black line corresponds to the ligand, the red line corresponds to the stoichiometric addition of copper(II) ions, and the blue one corresponds to the excess of copper(II) ions.

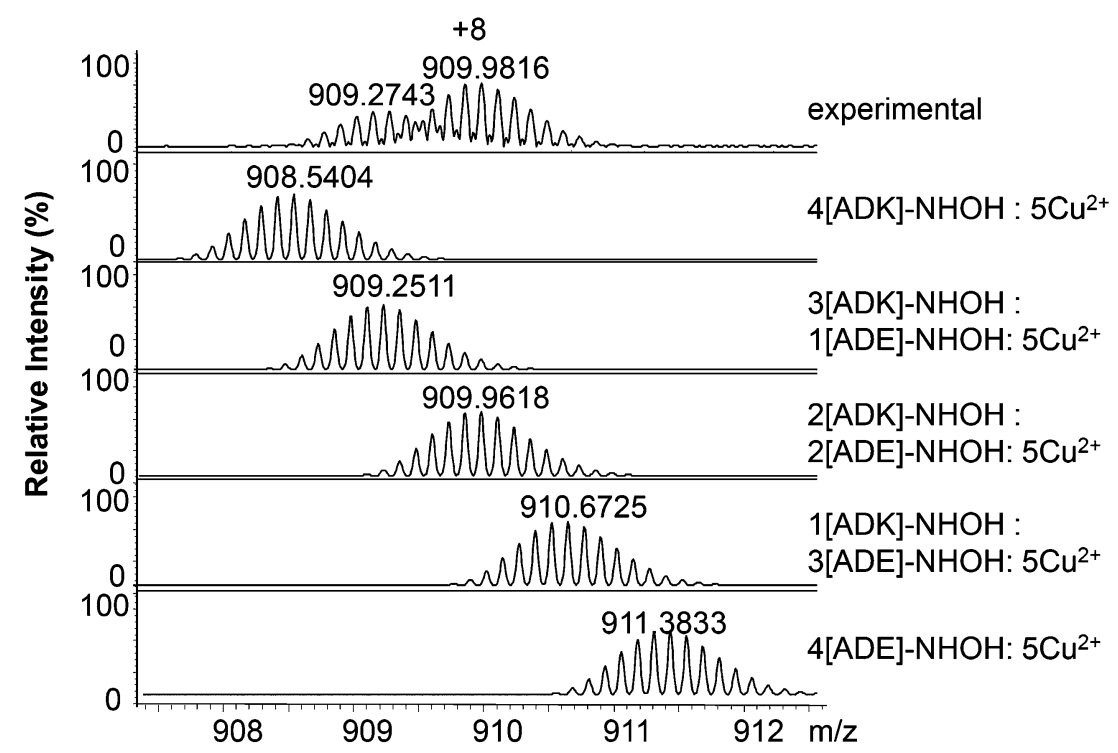

Fig. 2 The isotopic pattern of the peak of $m / z=908.5404$ for a "mixed" system (composed of [ADK]-NHOH, [ADE]-NHOH, and copper(I) ions). On the top the experimental data are shown and compared with the calculated ones (lower panels). The stoichiometries for all complexes are given on the right. 


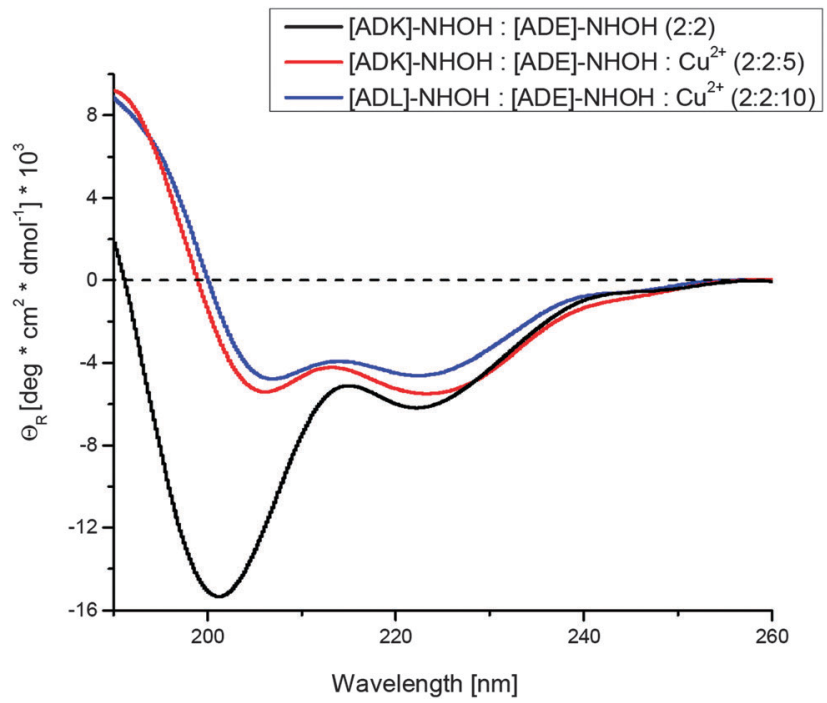

Fig. 4 The CD spectra of a mixture of peptides [ADK]-NHOH and [ADE]-NHOH and their complexes with copper(II) ions.

The spectra of investigated compounds (here presented for peptides $[\mathrm{AD}]-\mathrm{NHOH}$ and $[\mathrm{AD}]-\mathrm{NH}_{2}$ ) show a strong negative band, which is accompanied by a negative shoulder at $210-220 \mathrm{~nm}$. The $\mathrm{CD}$ spectra of $[\mathrm{ADK}]-\mathrm{NHOH}$ and $[\mathrm{ADE}]-\mathrm{NHOH}$ peptides demonstrate that the conformational equilibrium of these compounds is dominated by open conformations while peptides [AD]-NHOH, $[\mathrm{AH}]-\mathrm{NHOH}$, and [AH1]-NHOH are characterized by some fraction of the helical or $\beta$-turn conformation. ${ }^{12}$

The addition of $\mathrm{Cu}^{2+}$ ions (ratio corresponding to the metallacrown stoichiometry) drastically changes the CD spectrum of [AD]-NHOH (Fig. 3). There are two negative bands at 206 and $220 \mathrm{~nm}$ accompanied by a strong positive band at $190 \mathrm{~nm}$. The spectrum is very similar to that characteristic of the $\alpha$-helical conformation. The spectra of peptides [AH]-NHOH and [AH1]$\mathrm{NHOH}$ in solutions containing $\mathrm{Cu}^{2+}$ as well as the spectrum of [ADK]-NHOH (ESI $\dagger$ ) are essentially the same. However, the spectral changes of the [ADE]-NHOH peptide induced by addition of $\mathrm{Cu}^{2+}$ ions are much less pronounced. Interestingly, a mixture of the $[\mathrm{ADE}]-\mathrm{NHOH}$ and $[\mathrm{ADK}]-\mathrm{NHOH}$ peptides in the presence of $\mathrm{Cu}^{2+}$ shows the spectrum suggesting the domination of the helical conformation (Fig. 4). Unfortunately, a partial precipitation of the reaction product influences the measured ellipticity and makes measurements less reproducible. A control experiment was also performed on the $[\mathrm{AD}]-\mathrm{NH}_{2}$ peptide. In this case, the changes in the $\mathrm{CD}$ spectrum upon $\mathrm{Cu}^{2+}$ addition were negligible (Fig. 3).

\section{Enzymatic hydrolysis}

Peptides [AD]- $\mathrm{NH}_{2}$ and [AD]-NHOH were incubated with trypsin in the presence and absence of $\mathrm{Cu}^{2+}$ ions. The results after 20 min of incubation are presented in Fig. 5. In panels B-D (peptide $[\mathrm{AD}]-\mathrm{NHOH}$ without $\mathrm{Cu}^{2+}$ ions and peptide $[\mathrm{AD}]-\mathrm{NH}_{2}$ with and without $\mathrm{Cu}^{2+}$ ), the predominant peaks correspond to proteolytic fragments. Only in panel A, representing a spectrum of peptide $[\mathrm{AD}]-\mathrm{NHOH}$ in the presence of $\mathrm{Cu}^{2+}$ ions,
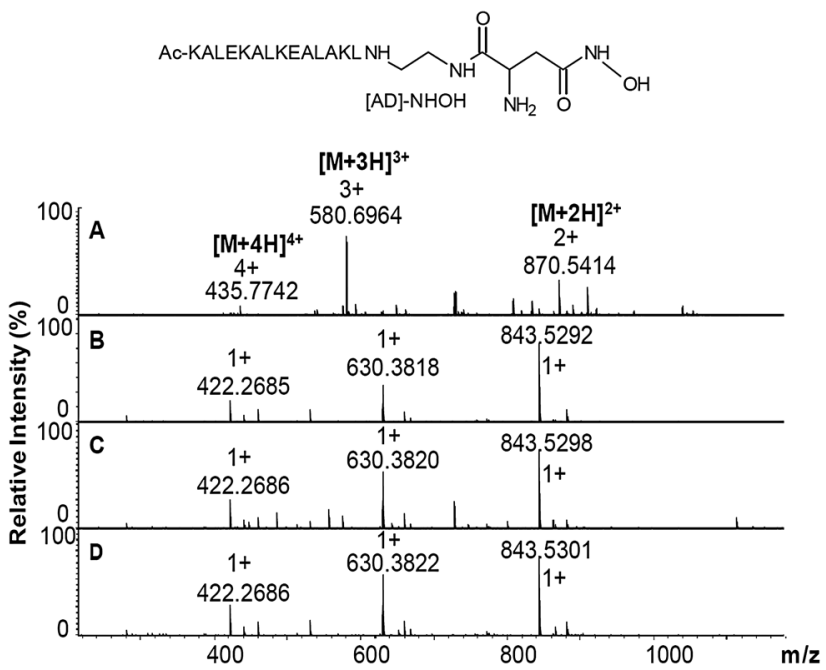

Fig. 5 Enzymatic hydrolysis of $[A D]-\mathrm{NHOH}$ and $[A D]-\mathrm{NH}_{2}$ peptides and their copper(II) complexes. Panel A: [AD]-NHOH + $\mathrm{Cu}^{2+} ; \mathrm{B}:[A D]-\mathrm{NHOH}^{2} \mathrm{C}:[A D]-\mathrm{NH}_{2}$; D: $[A D]-\mathrm{NH}_{2}+\mathrm{Cu}^{2+}$. In panel $A$, all marked peaks correspond to the unhydrolyzed ligand. In panels $B-D$, they correspond to the hydrolyzed fragments: [3-10] (calc. $m / z=843.5290$ ) and [11-15] (calc. $m / z=630.3821$ ).

the predominant peak corresponds to an unhydrolyzed ligand, which suggests that the complexation resulting in formation of an ordered helical structure protects the peptide chains from the enzymatic hydrolysis. In the spectrum (Fig. 5A) metallacrown is not observed due to acidic $\mathrm{pH}$. The addition of $10 \%$ TFA was needed to quench the enzymatic hydrolysis reaction. At acidic $\mathrm{pH}$ the complex bonds in metallacrown systems were decomposed. Moreover MS measurements were performed in the mixtures containing $0.1 \% \mathrm{HCOOH}$, which prevented the reconstruction of metallacrowns.

\section{NMR experiments}

Free peptide. The NMR investigations carried out in the free form of the [AD]- $\mathrm{NHOH}$ peptide dissolved in $\mathrm{D}_{2} \mathrm{O}$ allowed us to assign all amino acid spin systems. The $\mathrm{H} \alpha-\mathrm{C} \alpha$ chemical shifts of the free peptide are in agreement with the $\mathrm{CD}$ data indicating predominantly the open conformation. ${ }^{13}$

Addition of $\mathrm{Cu}^{2+}$ ions. Addition of paramagnetic $\mathrm{Cu}^{2+}$ ions caused significant changes in $1 \mathrm{D}^{1} \mathrm{H}$ and $2 \mathrm{D}{ }^{1} \mathrm{H}^{13} \mathrm{C}$ HSQC. Several ${ }^{1} \mathrm{H}^{13}{ }^{13} \mathrm{C}$ correlations were broadened beyond the detection limit due to the dipole-dipole interaction between the nuclei and the unpaired electron of $\mathrm{Cu}^{2+}$ and the long electron relaxation time of $\mathrm{Cu}^{2+}$ (Fig. 6A-C) Disappearance of the $\beta \mathrm{ahx}$ and adjacent Leu signals from the $2 \mathrm{D}^{1} \mathrm{H}^{-13} \mathrm{C}$ HSQC spectrum allowed us to unambiguously identify the binding sites of the metal that is in line with metallacrown formation. While the majority of $\mathrm{H} \alpha-\mathrm{C} \alpha$ correlations are moved downfield, the side-chain signals after $\mathrm{Cu}^{2+}$ addition occupy the same positions as in the free peptide indicating a fast exchange between the bound and free peptides. Only the $\mathrm{C} \beta$ chemical shifts of alanines are moved slightly upfield by $\sim 0.3 \mathrm{ppm}$. The downfield and upfield changes of the $\mathrm{C} \alpha(\sim 0.9-1.4 \mathrm{ppm})$ and $\mathrm{C} \beta$ chemical shifts of selected residues relative to the free peptide 

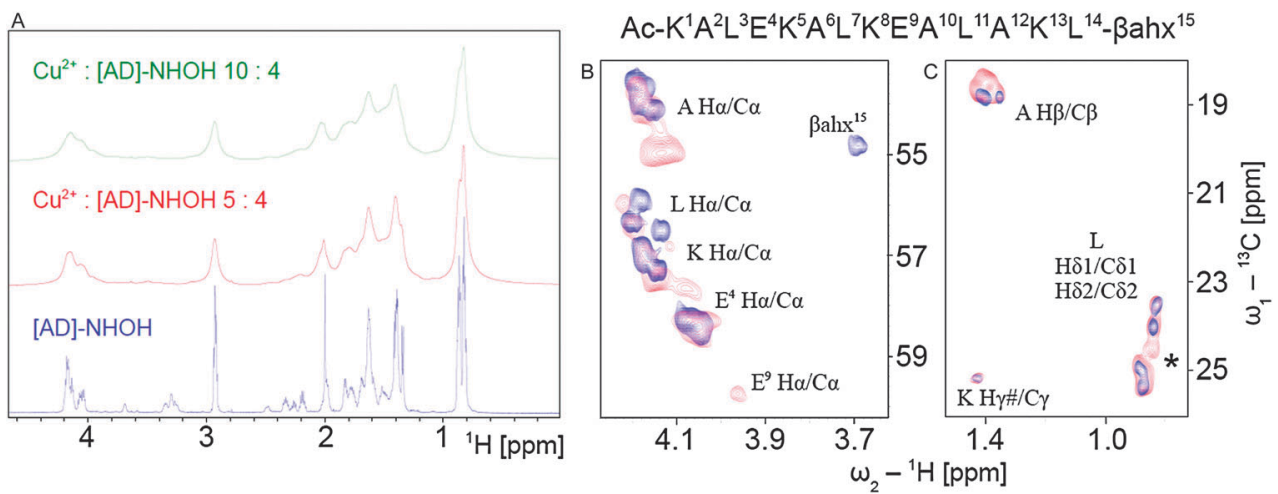

Fig. 6 (A) The $1 \mathrm{D}{ }^{1} \mathrm{H}$ spectra in $\mathrm{D}_{2} \mathrm{O}$ of the [AD]-NHOH peptide alone (blue), at the ligand: $\mathrm{Cu}^{2+}$ ratio of $4: 5$ (red), and at 2.5 excess of metal (green). (B) Superimposition of the $\mathrm{H} \alpha-\mathrm{C} \alpha$ signals of specific amino acid residues and amino acid types in the $2 \mathrm{D}{ }^{1} \mathrm{H}-{ }^{13} \mathrm{C} \mathrm{HSQC}$ spectra before (blue) and after (red) $\mathrm{Cu} \mathrm{U}^{2+}$ addition. (C) Superimposition of the side-chain ${ }^{1} \mathrm{H}-{ }^{13} \mathrm{C}$ signals in the $2 \mathrm{D}{ }^{1} \mathrm{H}-{ }^{13} \mathrm{C} \mathrm{HSQC}$ spectra before (blue) and after (red) $\mathrm{Cu}^{2+}$ addition. The signal marked with * of $\mathrm{H} \delta / \mathrm{C} \delta$ methyl groups of Leu14 clearly proves an adjacent change due to the metallacrown formation. Signals of the side-chain groups of other leucines, lysines, and glutamines remain unchanged upon $\mathrm{Cu}^{2+}$ addition, which suggests no formation of the hydrophobic core in a newly formed structure.

might be attributed to the $\mathrm{Cu}^{2+}$ induced pseudo-contact shifts. ${ }^{14}$ Taking into account the $\mathrm{CD}$ spectrum of the investigated peptide, it may be concluded that these shifts rather than pseudocontact ones correspond well to the increased helical propensity of the peptide backbone. At the stoichiometric ligand: $\mathrm{Cu}^{2+}$ ratio of $4: 5$ and at the 2.5 excess of metal, essentially the same NMR spectrum was obtained (Fig. 6A). Together with the fast exchange regime, this is in line with observations from $\mathrm{CD}$ that the stable metallacrowns are predominantly formed at the stoichiometric ratio $\left(\mathrm{L}_{4} \mathrm{Cu}_{5}\right)$. Unfortunately, due to a severe signal overlap we were unable to investigate the longitudinal paramagnetic relaxation of the ${ }^{1} \mathrm{H}$ nuclei. Because of broadening and loss of many signals it was impossible to unambiguously complete the sequence specific assignment of the peptide $\mathrm{Cu}^{2+}$-bound form spectrum (Fig. 6B), amino acid residues whose $\mathrm{C} \alpha$ and $\mathrm{C} \beta$ resonances (3 out of 4 Ala, one Glu) undergo specific shifts based on the primary sequence and well resolved 2D HSQC can conclude that the minimal length of the helix is 7 aa comprising the Ala-Leu-Lys-Glu-Ala-Leu-Ala fragment. Comparison of this result with CD studies where $c a$. $60 \%(8-10 \mathrm{aa})$ of the 15 aa peptide appears to be helical supports this conclusion. The only resonance that splits into two after $\mathrm{Cu}^{2+}$ addition ( $4: 5$ ratio) is the N-terminal acetyl moiety what indicates a possible exchange between different conformations of the less ordered N-terminal part of the folded peptide. ${ }^{14}$ After further addition of $\mathrm{Cu}^{2+}$ ions ( $4: 10$ ratio), the relative intensities of these two peaks are not changed. The lack of changes in positions of the side-chains of leucines 3,7 , and 11 , as well as of lysines and glutamic acids, suggests that the resulting tetrahelical bundle despite its compact nature is more a molten globule than a well packed structured hydrophobic core (Fig. 6C). Therefore, also the possible salt-bridges between the side chains of Glu and Lys stabilizing the four-helices tertiary structure can be excluded. ${ }^{15}$

Discussion. The mass spectrometric measurements demonstrate unambiguously that peptides containing a $\beta$-aminohydroxamic or an imidazoilo hydroxamic moiety at C-termini formed the supramolecular structures with the compositions corresponding to those of metallacrowns. The molecular masses of formed supramolecules (approx. $7200 \mathrm{Da}$ ) are comparable with those of ubiquitin or cytochrome $c$. The relatively high abundance of the $\mathrm{L}_{4} \mathrm{Cu}_{5}$ complex suggests that this system is predominant in solution. In addition, the metallacrown obtained is the only form of $\mathrm{Cu}^{2+}$-hydroxamate complexes detected by the ESI-MS method. The collision-induced-dissociation experiment revealed a high stability of the investigated supramolecule. This result is similar to that obtained previously for trimers of peptides containing a bipyridyl moiety. ${ }^{16}$ The high stability distinguishes the systems formed here from unspecific clusters of peptides often observed in ESI experiments. The literature reports on the metallacrowns formed by the hydroxamic acids indicate a good correlation between the composition of complexes in solution and that observed in the gas phase by the ESI method. ${ }^{17} \mathrm{~A}$ control experiment performed on the $[\mathrm{AD}]-\mathrm{NH}_{2}$ peptide proves that the metallacrown formation requires the hydroxamate moiety and cannot be considered as a property of the peptide sequence itself.

Mass spectrometry is a well established method for studying supramolecular assemblies, including cation-bound systems. Recently, the binding of an ammonium ion by DNA G-quadruplexes has been analysed. ${ }^{18}$ In this system, the stoichiometry of the complex formed in the gas phase depends significantly on the instrument type and ion source conditions, e.g. declustering potential. In our case, the spectra measured using two different instruments (micrOTOF-Q and Apex-ultra) were almost the same and the influence of experimental settings on spectra was negligible which may indicate that mass spectra reflect the stoichiometry of supramolecules in solution. Based on those results, we consider mass spectrometry as a method suitable for studying the interactions of peptides bearing the aminohydroxamate group with $\mathrm{Cu}^{2+}$ ions.

The character of the $\mathrm{CD}$ spectra of peptides $[\mathrm{AD}]-\mathrm{NHOH}$, $[\mathrm{AD}]-\mathrm{NHOH},[\mathrm{AH}]-\mathrm{NHOH}$, and [AH1]-NHOH in the presence of $\mathrm{Cu}^{2+}$ indicates a high content of helical structures in the conformational equilibrium. The helix content for peptide $[\mathrm{AD}]-\mathrm{NHOH}$ was estimated according to the procedure described in the literature. ${ }^{19}$ The $\alpha$-helix content is about $61 \%$ for the stoichiometric amount of $\mathrm{Cu}^{2+}$ ions and $65 \%$ when the twofold excess of $\mathrm{Cu}^{2+}$ ions with respect to the stoichiometric ratio was applied. The residual 


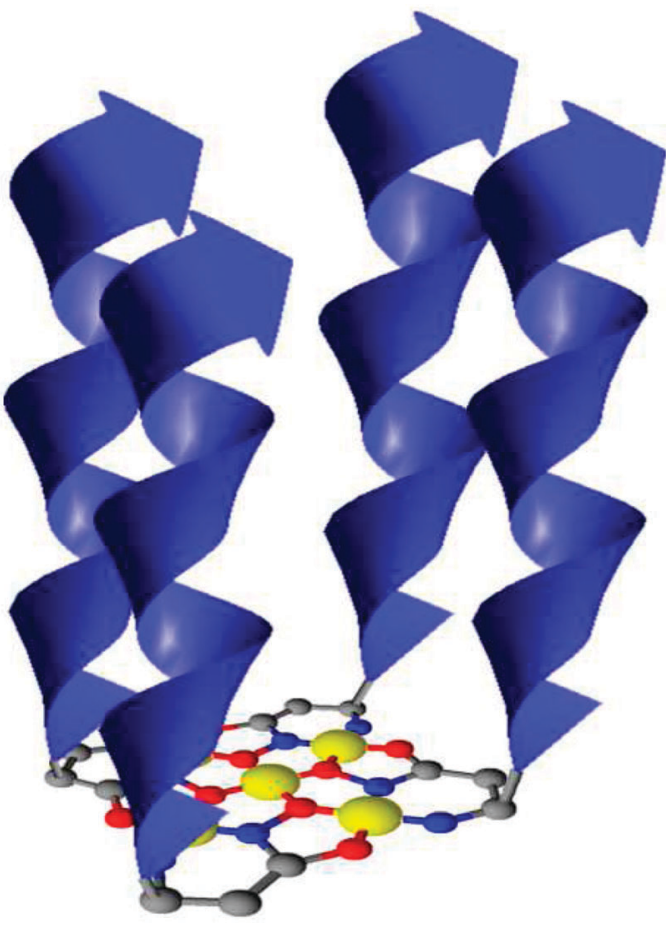

Fig. 7 Schematic representation of the supramolecular structure with 4 polypeptide chains assembled on the metallacrown template.

molar ellipticity measured in our system in the presence of $\mathrm{Cu}^{2+}$ $\left([\Theta]=-21600 \mathrm{deg} \mathrm{cm}^{2} \mathrm{dmol}^{-1}\right)$ is very close to that reported by Mutter $^{20}\left([\Theta]=-22000 \mathrm{deg} \mathrm{cm}^{2} \mathrm{dmol}^{-1}\right)$ for TASP molecules based on a sequence similar to that used in our study (EALEKALKEALAKLG). These data may indicate that in the metallacrown system investigated herein amphiphilic peptide chains interact in the same way as was reported for TASP. In a $\mathrm{CD}$ experiment the [AD]- $\mathrm{NH}_{2}$ peptide does not show distinct changes upon addition of $\mathrm{Cu}^{2+}$ ions. This result is similar to that obtained by the MS method and indicates the crucial role of the hydroxamate moiety in the investigated interactions.

The analysis of ESI-MS, NMR, and CD data indicates that the peptides containing the hydroxamic moiety in the C-terminal part form tetrameric structures in the presence of $\mathrm{Cu}^{2+}$ ions. Tetramerization observed in this system is connected with a shift in the conformational equilibrium toward helical structures (Fig. 7). This behaviour is also reflected by a much higher enzymatic stability of the tetrameric complex in comparison to other systems which are not able to form metallacrowns. The fact that folded polypeptide chains are much less susceptible to proteolysis is widely known. ${ }^{21}$ It may suggest that hydroxamate metallacrowns based on the amphiphilic sequences present some properties of folded proteins, such as a high content of helical conformation and stability against proteolysis.

\section{Conclusions}

In summary, the peptide hydroxamic acids based on the amphiphilic structures form a relatively simple and convenient system for studying the self-assembly of oligopeptides into tetrahelical bundles. The simplicity of ligand synthesis and preparation of complexes, possibility of mixed complexes formation, as well as geometrical properties similar to that of TASP make this system attractive for dynamic combinatorial chemistry.

\section{Experimental section}

\section{General peptide synthesis}

SPPS of peptides was performed manually in polypropylene syringe reactors (Intavis AG) equipped with polyethylene filters, on a modified ChemMatrix resin ${ }^{11}$ designed for synthesis of hydroxamic acid peptides. The synthesis was carried out according to the standard Fmoc procedure. The Fmoc-protecting groups were removed using $25 \%$ piperidine solution in DMF. The coupling reactions were performed in DMF using TBTU (3 eq.) in the presence of DIEA ( 3 eq.). The peptides were cleaved from the resin using a solution of TFA- $\mathrm{H}_{2} \mathrm{O}$-Tis $(95: 2.5: 2.5)$ at room temperature for $2 \mathrm{~h}$. The peptides were isolated after evaporation of TFA in a nitrogen stream.

The analytical data of obtained peptides are as follows:

Peptide [AH]-NHOH: HRMS (ESI) $=\mathrm{m} / z$ calcd for $\mathrm{C}_{78} \mathrm{H}_{138} \mathrm{~N}_{22} \mathrm{O}_{21}+2 \mathrm{H}^{+}$: $860.5276[\mathrm{M}+2 \mathrm{H}]^{2+}$; found: 860.5226; $R_{\mathrm{t} 1} 28.2 \mathrm{~min}, R_{\mathrm{t} 2} 26.0 \mathrm{~min}$.

Peptide [AH1]-NHOH: HRMS (ESI) $\mathrm{m} / \mathrm{z}$ calcd for $\mathrm{C}_{81} \mathrm{H}_{143} \mathrm{~N}_{23} \mathrm{O}_{22}+2 \mathrm{H}^{+}$: $896.0462[\mathrm{M}+2 \mathrm{H}]^{2+}$; found 896.0466; $R_{\mathrm{t} 1} 30.4 \mathrm{~min}, R_{\mathrm{t} 2} 25.6$ min.

Peptide [AD]-NHOH: HRMS (ESI) $\mathrm{m} / \mathrm{z}$ calcd for $\mathrm{C}_{78} \mathrm{H}_{142} \mathrm{~N}_{22} \mathrm{O}_{22}+2 \mathrm{H}^{+}: 870.5407[\mathrm{M}+2 \mathrm{H}]^{2+}$; found 870.5404; $R_{\mathrm{t} 1} 28.8$ min, $R_{\mathrm{t} 2} 26.4$ min.

Peptide [ADK]-NHOH: HRMS (ESI): $\mathrm{m} / \mathrm{z}$ calcd for $\mathrm{C}_{80} \mathrm{H}_{152} \mathrm{~N}_{24} \mathrm{O}_{18}+2 \mathrm{H}^{+}$: $869.5931[\mathrm{M}+2 \mathrm{H}]^{2+}$; found: 869.5934; $R_{\mathrm{t} 1} 25.4 \mathrm{~min}, R_{\mathrm{t} 2} 22.5 \mathrm{~min}$.

Peptide [ADE]-NHOH: HRMS (ESI): $\mathrm{m} / \mathrm{z}$ calcd for $\mathrm{C}_{74} \mathrm{H}_{120} \mathrm{~N}_{18} \mathrm{O}_{30}+2 \mathrm{H}^{+}: 872.4360[\mathrm{M}+2 \mathrm{H}]^{2+}$; found: 872.4363 ; $R_{\mathrm{t} 1} 36.6 \mathrm{~min}, R_{\mathrm{t} 2} 30.2 \mathrm{~min}$.

Peptide [AD]- $\mathrm{NH}_{2}$ : HRMS (ESI): $\mathrm{m} / z$ calcd for $\mathrm{C}_{78} \mathrm{H}_{142} \mathrm{~N}_{22} \mathrm{O}_{21}$ $+2 \mathrm{H}^{+}: 862.5433[\mathrm{M}+2 \mathrm{H}]^{2+} ;$ found: 862.5433; $R_{\mathrm{t} 1} 31.0 \min , R_{\mathrm{t} 2}$ $27.4 \mathrm{~min}$.

Additional analytical data (NMR of [AD]-NHOH and ESI-MS/ MS for all peptides) have been presented in a previous paper. ${ }^{11}$

\section{Purification}

All crude products were analyzed by analytical HPLC using a Thermo separation HPLC system with UV detection $(210 \mathrm{~nm})$ on a Vydac Protein RP C18 column $(250 \times 4.6 \mathrm{~mm}, 5 \mu \mathrm{m})($ Grace, Deerfield, IL, USA), with a gradient elution of $0-80 \%$ B in A (A = $0.1 \%$ TFA in water; $\mathrm{B}=0.1 \%$ TFA in acetonitrile- $\mathrm{H}_{2} \mathrm{O}, 4: 1$ ) for $45 \mathrm{~min}$ (flow rate $1 \mathrm{ml} \mathrm{ml}^{-1}$, rt). For all compounds additional HPLC analysis was performed on a Varian Microsorb-MV 100-5 CN column ( $4.6 \mathrm{~mm} \times 250 \mathrm{~mm}$; Varian, Palo Alto, CA, USA) in the same gradient system. Retention times are given as $R_{\mathrm{t} 1}$ and $R_{\mathrm{t} 2}$, respectively. Preparative reversed-phase HPLC was performed on a Tosoh TSKgel ODS-120T column $(21.5 \mathrm{~mm} \times 300 \mathrm{~mm})$ (Tosoh, Tokyo, Japan) using the same solvent system, gradient $0.5 \%$

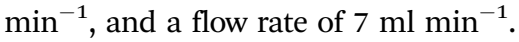




\section{Mass spectrometry}

The compounds investigated were dissolved in methanol: $\mathrm{NH}_{4} \mathrm{HCO}_{3}$ solution $\left(1: 1,10^{-2} \mathrm{M}\right)$. The MS experiments were performed on an FT-ICR (ion cyclotron resonance) MS Apex-Qe Ultra 7T instrument (Bruker Daltonics, Germany) equipped with an ESI source. Argon was used as a collision gas. The instrument was operated in a positive and a negative ion mode and calibrated with Tunemix ${ }^{\mathrm{TM}}$ (Bruker Daltonics, Germany). The instrumental parameters were as follows: temperature of the drying gas was $200{ }^{\circ} \mathrm{C}$, the potential between the spray needle and the orifice was set to $4.5 \mathrm{kV}$, source accumulation $1.0 \mathrm{~s}$, and ion accumulation time $1.0 \mathrm{~s}$. The MS spectra were also recorded on a Bruker micrOTOF-Q mass spectrometer equipped with an Apollo II electrospray ionization source. The instrumental parameters were as follows: scan range $\mathrm{m} / \mathrm{z}$ 300-1600, dry gas - nitrogen $\left(3 \mathrm{~L} \mathrm{~min}^{-1}\right)$, temperature $200{ }^{\circ} \mathrm{C}$.

\section{Circular dichroism}

CD spectra were recorded on a Jasco J-600 spectropolarimeter. Peptides were dissolved in ammonium carbonate buffer $\left(10^{-2} \mathrm{M}\right)$ at the concentration of $10^{-4} \mathrm{M}$. The complexes were obtained in stoichiometric mixtures of ligand: $\mathrm{Cu}^{2+}$ $\left(4: 5,10^{-2} \mathrm{M}: 1.25 \times 10^{-2} \mathrm{M}\right)$ and at the excess of copper(II) ions (ligand: $\mathrm{Cu}^{2+} 4: 10$ ). The $\mathrm{pH}$ range was 7.5-8.0. The spectrum of the solvent was recorded under identical conditions and subtracted during data analysis. A rectangular quartz cell of $1 \mathrm{~mm}$ path length was used. The data are presented as mean residue molar ellipticity $[\Theta]$. The concentrations of peptides used for the $\mathrm{CD}$ experiments were verified based on the nitrogen content determined by elemental analysis.

\section{Nuclear magnetic resonance (NMR)}

All NMR measurements for the [AD]-NHOH peptide and its $\mathrm{Cu}^{2+}$ complex were done on Bruker Avance and Varian Unity + $500 \mathrm{MHz}$ spectrometers, at $25{ }^{\circ} \mathrm{C}$ in $99 \% \mathrm{D}_{2} \mathrm{O}$ ammonium carbonate buffer $\left(10^{-2} \mathrm{M}\right)$ at $\mathrm{pH} 7.8(2 \mathrm{mg}$ peptide in $650 \mu \mathrm{l})$. The spectra used for resonance assignments of the $[\mathrm{AD}]-\mathrm{NHOH}$ peptide spin systems before and after addition of $\mathrm{Cu}^{2+}$ (ligand : $\mathrm{Cu}^{2+}$ ratios $4: 5$ and $4: 10$ ), i.e. the $2 \mathrm{D}{ }^{1} \mathrm{H}-{ }^{1} \mathrm{H}$ TOCSY (20 and $80 \mathrm{~ms}$ mixing times), ${ }^{1} \mathrm{H}-{ }^{1} \mathrm{H}$ ROESY (300 ms), ${ }^{1} \mathrm{H}-{ }^{1} \mathrm{H}$ NOESY (100 and $500 \mathrm{~ms}$ ), and ${ }^{1} \mathrm{H}-{ }^{13} \mathrm{C}$ HSQC spectra were processed by NMRpipe ${ }^{22}$ and analyzed in Sparky (T. D. Goddard and D. G. Kneller, http://www.cgl.ucsf.edu/home/sparky).

\section{Enzymatic hydrolysis}

Briefly, the peptides $(0.1 \mathrm{mg})$ were dissolved in $\mathrm{NH}_{4} \mathrm{HCO}_{3}$ buffer solution $\left(0.575 \mathrm{ml}, 10^{-2} \mathrm{M}, \mathrm{pH} 7.8\right)$. Then a $10 \mu \mathrm{l}$ aliquot of the trypsin stock solution $(0.1 \mathrm{mg}$ in $1 \mathrm{ml}$ of water) was added to obtain the $1: 100$ enzyme:substrate $(\mathrm{w} / \mathrm{w})$ ratio. The reaction mixtures were incubated at $37{ }^{\circ} \mathrm{C}$ for $20 \mathrm{~min}, 40 \mathrm{~min}, 1 \mathrm{~h}$, and $2 \mathrm{~h}$. The reaction was quenched by addition of $10 \%$ aqueous trifluoroacetic acid $(150 \mu \mathrm{l})$. The resulting digest was lyophilized and used for MS experiments. The experiments with copper(II) ions were performed similarly to those mentioned above. Briefly, the peptides $(0.1 \mathrm{mg})$ were dissolved in $\mathrm{NH}_{4} \mathrm{HCO}_{3}$ buffer $(0.575 \mathrm{ml})$ and to this solution $\mathrm{CuSO}_{4}(18 \mu \mathrm{l})$ was added (stock solution $1 \mathrm{mg}$ per $1 \mathrm{ml})$. Then $10 \mu \mathrm{l}$ of the trypsin stock solution ( $0.1 \mathrm{mg}$ in $1 \mathrm{ml}$ water) was added. Further conditions have been previously described.

\section{Acknowledgements}

This work was financially supported by Grant no. UMO-2012/ 07/B/ST5/00821 from National Science Center of Poland.

\section{Notes and references}

1 (a) M. Mutter and S. Vuilleumier, Angew. Chem., Int. Ed. Engl., 1989, 28, 535-554; (b) M. Mutter, Trends Biochem. Sci., 1988, 13, 260-265; (c) M. Mutter and G. Tuchscherer, Cell. Mol. Life Sci., 1997, 53, 851-863.

2 (a) G. Tuchscherer and M. Mutter, J. Biotechnol., 1995, 41, 197-210; (b) M. Mutter, G. G. Tuchscherer, C. Miller, K. H. Altmann, R. I. Carey, D. F. Wyss, A. M. Labhardt and J. E. Rivier, J. Am. Chem. Soc., 1992, 114, 1463-1470; (c) P. Dumy, I. M. Eggleston, S. Cervigini, U. Sila, X. Sun and M. Mutter, Tetrahedron Lett., 1995, 36, 1255-1258; (d) K. J. Jensen and J. Brask, Cell. Mol. Life Sci., 2002, 59, 859-869; (e) K. S. Akerfeldt, R. M. Kim, D. Camac, J. T. Groves, J. D. Lear and W. F. DeGrado, J. Am. Chem. Soc., 1992, 114, 9656-9657; $(f)$ H. E. K. Huttunen-Hennelly and J. C. Sherman, Org. Biomol. Chem., 2007, 5, 3637-3650; $(g)$ J. O. Freeman, W. C. Lee, M. E. P. Murphy and J. C. Sherman, J. Am. Chem. Soc., 2009, 131, 7421-7429.

3 (a) R. P. Cheng, S. L. Fisher and B. Imperiali, J. Am. Chem. Soc., 1996, 118, 11349-11356; (b) A. J. Doerr and G. L. McLendon, Inorg. Chem., 2004, 43, 7916-7925; (c) J. M. C. A. Kerckhoffs, M. Crego-Calama, I. Luyten, P. Timmerman and D. N. Reinhoudt, Org. Lett., 2000, 2, 4121-4124.

4 (a) M. Lieberman and T. Sasaki, J. Am. Chem. Soc., 1991, 113, 1470-1471; (b) M. R. Ghadiri, C. Soares and C. Choi, J. Am. Chem. Soc., 1992, 114, 4000-4002.

5 B. Kurzak, H. Kozłowski and E. Farkas, Coord. Chem. Rev., 1992, 114, 169-200.

6 D. Xia, C.-A. Yu, H. Kim, J.-Z. Xia, A. M. Kachurin, L. Zhang, L. Yu and J. Deisenhofer, Science, 1997, 277, 60-66.

7 (a) J. A. Halfen, J. J. Bodwin and V. L. Pecoraro, Inorg. Chem., 1998, 37, 5416-5417; (b) J. J. Bodwin, A. D. Cutland, R. G. Malkani and V. L. Pecoraro, Coord. Chem. Rev., 2001, 216-217, 489-512; (c) M. Tegoni and M. Remelli, Coord. Chem. Rev., 2012, 256, 289-315.

8 M. Tegoni, M. Remelli, D. Bacco, L. Marchió and F. Dallavalle, Dalton Trans., 2008, 2693-2701.

9 (a) E. Caspo, P. Buglyo, N. Y. Nagy, M. A. Santos, A. Corona and E. Farkas, Polyhedron, 2010, 29, 3137-3145; (b) E. Farkas, E. Csapó, P. Buglyo, C. D. Damante and G. D. Natale, Inorg. Chim. Acta, 2009, 362, 753-762.

10 A. Grove, M. Mutter, J. E. Rivier and M. Montal, J. Am. Chem. Soc., 1993, 115, 5919-5924.

11 M. Cal, M. Jaremko, Ł. Jaremko and P. Stefanowicz, J. Pept. Sci., 2012, 19, 9-15.

12 K. Nakanishi, N. Berova and R. W. Woody, Circular Dichroism Principles and Applications, VCH, New York, 1994. 
13 J. Cavanagh, W. J. Fairbrother, A. G. Palmer III, N. J. Skelton and M. Rance, Protein NMR spectroscopy: principles and practice, Academic Press, Boston, 2nd edn, 2007.

14 M. R. Jensen and J. J. Led, Biochemistry, 2006, 45, 8782-8787.

15 M. Jaremko, Ł. Jaremko, H.-Y. Kim, M.-K. Cho, C. D. Schwieters, K. Giller, S. Becker and M. Zweckstetter, Nat. Chem. Biol., 2013, 9, 264-270, DOI: 10.1038/NChemBio.1181.

16 H. J. Cooper, M. A. Case, G. L. McLendon and A. G. Marshall, J. Am. Chem. Soc., 2003, 125, 5331-5339.

17 M. Zyrek, E. Gumienna-Kontecka, Z. Szewczuk, I. O. Fritsky and H. Kozłowski, ARKIVOC, 2009, 145-152.

18 F. Balthasart, J. Plavec and V. Gabelica, J. Am. Soc. Mass Spectrom., 2013, 24, 1-8.
19 (a) J. M. Scholtz, H. Qian, E. J. York, J. M. Stewart and R. L. Baldwin, Biopolymers, 1991, 31, 1463-1470; (b) B. Forood, E. J. Feliciano and K. P. Nambiar, Proc. Natl. Acad. Sci. U. S. A., 1993, 90, 838-842.

20 A. Grove, M. Mutter, J. E. Rivier and M. Montalt, J. Am. Chem. Soc., 1993, 115, 5919-5924.

21 (a) A. Fontanna, M. Zambonin, P. P. de Laureto, V. de Filippis, A. Clementi and E. Scaramella, J. Mol. Biol., 1997, 266, 223-230;

(b) C. Park and S. Marqusee, Nat. Methods, 2005, 2, 207-212;

(c) E. Mihalyi, Application of Proteolytic Enzymes to Protein Structure Studies, CRC Press, Boca Raton, FL, 1978.

22 F. Delaglio, S. Grzesiek, G. W. Vuister, G. Zhu, J. Pfeifer and A. Bax, J. Biomol. NMR, 1995, 6, 277-293. 